\title{
Economic Efficiency of Resource Recovery - Analysis of Time-Dependent Changes on Sustainability Perception of Waste Management Scenarios
}

\section{Tihomir Tomic ( $\nabla$ tihomir.tomic@fsb.hr)}

University of Zagreb Faculty of Mechanical Engineering and Naval Architecture: Sveuciliste u Zagrebu Fakultet Strojarstva i Brodogradnje https://orcid.org/0000-0003-1979-6590

Irma Kremer

University of Zagreb Faculty of Mechanical Engineering and Naval Architecture: Sveuciliste u Zagrebu Fakultet Strojarstva i Brodogradnje

\section{Daniel Rolph Schneider}

University of Zagreb Faculty of Mechanical Engineering and Naval Architecture: Sveuciliste u Zagrebu Fakultet Strojarstva i Brodogradnje

\section{Research Article}

Keywords: Resource recovery, Economic sustainability analysis, Waste management policies and legislation, Decision making, Environmental assessment, System planning

Posted Date: July 19th, 2021

DOI: https://doi.org/10.21203/rs.3.rs-192887/v1

License: (1) (1) This work is licensed under a Creative Commons Attribution 4.0 International License. Read Full License

Version of Record: A version of this preprint was published at Clean Technologies and Environmental Policy on July 30th, 2021. See the published version at https://doi.org/10.1007/s10098-021-02165-1. 


\title{
Economic Efficiency of Resource Recovery - Analysis of Time-Dependent Changes on Sustainability Perception of Waste Management Scenarios
}

\author{
Tihomir Tomić*1, Irma Kremer ${ }^{1}$, Daniel R. Schneider ${ }^{1}$ \\ ${ }^{1}$ Department of Energy, Power Engineering and Environment, Faculty of Mechanical \\ Engineering and Naval Architecture, University of Zagreb, Zagreb, Croatia
}

\begin{abstract}
Waste management systems are modelled to provide a public waste management service and need to be able to meet environmental sustainability requirements at a cost that is acceptable to system users/citizens. Overall environmental, economic, and/or socio-economic sustainability of waste management in previous publications is done through independent analyses and comparisons of obtained results or through multicriterial ranking of different alternatives where final results do not have a meaningful physical significance and cannot be interpreted independently. At the same time, those analysis either neglect time dependant changes by focusing on moment in time, or take into account changes in some timeframe changes but report only ranking focused single-score results, thus, results neglect time-dependent developments. All of these approaches are lacking some information needed for informed decision-making and/or are difficult to understand by wider groups of people. Thus, in this study, link between economic and environmental sustainability is analysed through newly defined single-score Economic Efficiency of Resource Recovery (EERR) index that shows the specific system cost for achieving identified resource recovery, while legislation based time dependent changes are taken into account through successive analyses for legislative most important years. This approach can be used for benchmarking the overall (environmental and economic) sustainability trends, while its graphical representation enables easier presentation of sustainability results and can be used for easier comparison of possible solutions and decisionmaking. The results show that the quality decision-making process needs to take into account the impact of expected changes on overall sustainability and evaluate how they will affect the actual perception of used technologies. In this context, it is shown that overall changes in sustainability, in comparison to the existing perception, can significantly change, depending on which technologies the system is based on.
\end{abstract}

\section{KEYWORDS}

Resource recovery, Economic sustainability analysis, Waste management policies and legislation, Decision making, Environmental assessment, System planning

\section{NOMENCLATURE}

$\begin{array}{ll}i & \text { investment cost }\left[€^{*}\right] \\ o & \text { operation and maintenance costs }\left[€ / \mathrm{t}^{*}\right] \\ c & \text { overall cost }[€] \\ x & \text { input waste stream [t/year] }\end{array}$

\footnotetext{
*Corresponding author. E-mail: tihomir.tomic@fsb.hr
} 


$\begin{array}{ll}y & \text { input biogas flow }\left[\mathrm{m}^{3} / \mathrm{h}\right] \\ z & \text { output flow of } \mathrm{CNG}\left[\mathrm{m}^{3} / \mathrm{h}\right] \\ S C C & \text { Specific system cost }[€ / \mathrm{t}] \\ R E E & \text { Recovery of Embodied Energy [\%] } \\ E E R R & \text { Economic Efficiency of Resource Recovery [€/t per \%] } \\ \text { " If not stated differently }\end{array}$

$\begin{array}{ll}\text { Abbreviations } \\ \text { MSW } & \text { Municipal solid waste } \\ \text { WM } & \text { Waste management } \\ \text { PPP } & \text { Polluter pays principle } \\ \text { EPR } & \text { Extended producer responsibility } \\ \text { WMH } & \text { Waste management hierarchy } \\ \text { WMS } & \text { Waste management system } \\ \text { LCA } & \text { Life cycle assessment } \\ \text { CED } & \text { Cumulative energy demand } \\ \text { LCIA } & \text { Life cycle impact assessment } \\ \text { PE } & \text { Primary energy } \\ \text { LCC } & \text { Life cycle cost } \\ \text { AD } & \text { Anaerobic digestion } \\ \text { AHP } & \text { Analytic hierarchy process } \\ \text { MCDM } & \text { Multiple-criteria decision-making } \\ \text { MCDA } & \text { Multiple-criteria decision analyses } \\ \text { EERR } & \text { Economic Efficiency of Resource Recovery } \\ \text { L } & \text { Landfill } \\ \text { MB } & \text { Mass burn } \\ \text { TT } & \text { Thermal treatment } \\ \text { CK } & \text { Cement kiln } \\ \text { CKwAD } & \text { Cement kiln with anaerobic digestion } \\ \text { G } & \text { Gasification } \\ \text { BM } & \text { Bio-methane } \\ \text { EL } & \text { Electricity } \\ \text { ET } & \text { Ethanol } \\ \text { CHP } & \text { Combined heat and power } \\ & \\ \end{array}$

\section{INTRODUCTION}

EU economic development as such is not only unsustainable from the standpoint of satisfying increasing material and energy consumption, but also from the point of output, i.e. the increasing generation of waste which do not fit into the established natural cycles. The total EU waste production in 2016 amounted to 2.3 billion $\mathrm{t}$, of which $48 \%$ was not recovered (Eurostat 2020a). Through this, the EU economy loses almost half of potential secondary raw materials, which are currently being dumped without recovery. The EU thus misses numerous opportunities to significantly improve resource efficiency and to establish a wider circular economy. It is estimated that up to 600 million t of discarded waste could be reused or recycled (European Commission 2020). When looking from the perspective of citizens, EU28 countries generate $4.97 \mathrm{t}$ of waste per capita. Excluding inert mineral wastes, this figure amounts to 1.77 t per capita, of which 33\% is municipal solid waste (MSW) (waste material from households and sources with waste similar to household waste) (Eurostat 2020b, 2020c). 
The first step towards solving this problem was made in 1999, through the European Waste Disposal Directive (Directive 1999/31/EC), which placed restrictions on waste disposal. Therefore, a reduction in the amount of biodegradable waste disposed of at municipal landfills by $25 \%$ to 2010 , by $50 \%$ to 2013 , and by $65 \%$ to 2020 (in comparison to 1995 ) was expected. In addition, Article 6(a) of the Waste Disposal Directive stipulates that all waste intended for landfilling must be treated first (except for inert materials) in order to increase the recovery rate (European Council 1999). The EU objectives in the field of MSW management for the period up to 2020 have been defined in 2008 by the Waste Framework Directive (Directive 2008/98/EC). This Directive defines the basic concepts of waste management (WM), waste recovery, and recycling. It also takes a step further through the introduction of the Polluter Pays Principle (PPP) and introduces the concept of Extended Producer Responsibility (EPR), which includes changes in product design with a goal of efficient use of resources throughout the product life cycle, including making its repair, recovery and recycling easier. In this context, the Waste Framework Directive sets out two main objectives to be met by $2020-70 \%$ of construction waste and $50 \%$ of individual municipal waste materials need to be prepared for reuse and recycling (European Parliament and Council 2008). Also, the established Waste Management Hierarchy (WMH) sets one of the basic principles of WM and gives the highest priority to avoiding waste generation, while the priority regarding the treatment of waste is given to material recovery. According to this principle, energy recovery is positioned after material recovery and is a preferred choice over disposal.

In the new Circular Economy Action Plan, the European Parliament and Council (2015) put emphasis on preparation for reuse and recycling of key waste streams. The main idea behind this plan is to gradually equalize the level of best practice across the EU Member States and to encourage the necessary investments in the field of WM. The Circular Economy Action Plan is part of a broader Circular Economy Package (European Commission 2015) that incorporates waste-related legislative changes in order to foster a European transition towards a Circular Economy. This path includes measures to increase resource efficiency and break the link between increasing material and energy consumption and the environmental impact of economic growth. Roadmap to a Resource Efficient Europe (European Commission 2011), as a part of Europe 2020 strategy, outlines that EU "faces the dual challenge of stimulating the growth needed to provide jobs and well-being to its citizens, and of ensuring that the quality of this growth leads to a sustainable future" and that to turn these challenges into opportunities EU economy "will require a fundamental transformation within a generation - in energy, industry, agriculture, fisheries and transport systems, and in producer and consumer behaviour". In this context, it proposes the Circular Economy as the best concept for the transformation in all areas. The Circular Economy introduces the concept of "Closing the Loop" in the life cycle of materials and products. The "Closing the Loop" between the end of the product life cycle and its production enables the circulation of resources, materials and products within the EU economy and thus keeps its energy, material and economic value within the economy. Emphasis is placed on avoiding waste production through better product design (eco-design), which leads to more durable products that are easier to disassemble, repair and ultimately recycle.

The longstanding debate on the Circular Economy Package, which has been ongoing since July 2014, resulted in the adoption of the Waste Package, which was published in the Official Journal of the European Union on 14 June 2018 (European Parliament 2018). This package introduces amendments to WM regulations and consists of four directives: Directive (EU) 2018/851 amending Directive 2008/98/EC on waste, Directive (EU) 2018/850 amending Directive 1999/31/EC on landfills, Directive (EU) 2018/852 amending Directive 94/62/EC on 
packaging and packaging waste, and Directive (EU) 2018/849 amending Directives 2000/53/EC on waste vehicles, Directive 2006/66/EC on batteries and accumulators and waste batteries and accumulators, and Directive 2012/19/EU on waste electrical and electronic equipment (European Parliament and Council 2018a, 2018b, 2018c, 2018d). The main features of the final acts include increased targets for the reuse and recycling of municipal waste of $60 \%$ by 2030 and $65 \%$ by 2035, increased targets for recycling of packaging waste of $70 \%$ by 2030 and introduction of limitation on disposal of municipal waste to $10 \%$ by 2035 . It also emphasizes the importance of the WMH and broadens the scope of measures that the Member States must implement in the area of waste prevention (including food waste). Waste Package also introduces provisions intending to avoid contamination of secondary raw materials; EPR schemes are becoming mandatory for packaging waste by 2024; and the requirements for separate waste collection are being tightened. Also, an outlook to the future is given and the European Commission is also requested to carry out an analysis of the EPR system; revise the Directive regarding vehicle end-of-life; consider implementing the new goal regarding the reduction of food waste generation; consider implementing goals regarding re-use, reducing of production, recovering and recycling of specific waste streams; and consider the introduction of quantitative (per capita) targets for waste disposal, packaging reuse and recycling.

In this path, European Parliament (2020) on January 15th, 2020 passed the European Green Deal proposals (2019/2956(RSP)) with a goal of implementation of "sustainable green transitions" through which Europe will look to become the world's "first climate-neutral continent by 2050 ". At the same time, the European Parliament called on the Commission to propose targets for separate collections and waste reduction. Members of the European Parliament also urged the Commission to develop legislation to address the problem of packaging waste and to ensure that all products with packaging that cannot be reusable/recyclable in an economically sustainable way are not allowed to be put on the EU market by 2030 .

From the previous WM legislation overview, it can be seen that it is a fast-developing domain of EU law-making that intersects with an overall sustainable development agenda. Not only WM goals were often changed during the last few decades, but they will also become more strict and challenging as WM is one of the pillars in the overall development of a sustainable economy i.e. European Green Deal. While waste management systems (WMS) need to support European efforts in the field of environmental sustainability, it is also important that their development is economically sustainable, and also their sustainability needs to be future-proof. This is especially important for new member states, as well as future member states, i.e. candidate countries. These countries are lagging behind EU standards in the WMS maturity, thus in waste separation/recovery, as well as economically, thus they can't handle investment in economically questionable/unsustainable solutions. On the other hand, those countries mainly rely on landfill-based WMS and need to implement the biggest changes to meet EU goals. Even though EU legislation emphasizes the importance of the material recovery of waste, the problem of waste cannot be solved only with recycling, and thus material and energy recovery technologies need to be implemented together, to complement each other (Kremer et al. 2020). As WMS are usually financed by the system users, the cost of these changes falls on the shoulders of the citizens, because of which this problem becomes not only an environmental but also an economic and social problem at the same time. Because of that, when planning future WMS, or changes in the existing one, next to the environmental sustainability, which importance is emphasised by the legislative framework, also economical sustainability of the planned investments need to be looked upon, as without it no changes in existing WM can be expected. 
Due to the goal of achieving a sustainable economy, integrated municipal WMS has been analysed from many aspects. While no aspect should be overlooked, the Life Cycle Assessment (LCA) approach gained importance because of the Waste Framework Directive, which states that potential deviations from the waste hierarchy must be justified through analysis of life cycle impacts. This is often achieved through LCA analysis, which is a standardized scientific method for life-cycle impact assessment. The basic framework of LCA analysis was adopted through the standards ISO 14040 and 14044 by the International Standardization Organization (2006a, 2006b). Also, the Commission of the European Communities (2003) has emphasized LCA analysis as "the best framework for assessing the potential environmental impacts of products". This development leads to the increased interest of the scientific community in the topic of sustainability which generated a wide range of environmental reports while neglecting specific performance indicators (da Costa et al. 2020). On the other hand, it has been identified that direct LCA of alternative WMS should be avoided, in terms of material and energy recovery of waste materials, in favour of other LCA based indicators such as the Cumulative Energy Demand (CED) which is also used in Life Cycle Impact Assessment (LCIA) (Bueno et al. 2015). This conclusion is based on the properties of the CED assessment methodology, which combines energy and material flows, as well as related environmental impacts, into one size, thus enabling simultaneous assessment and comparison of the life cycles of material and energy flows. It enables the analysis of systems that combine the consumption and production of energy and material flows which are of a very different nature and not directly comparable or interchangeable. The CED factor represents the total primary energy (PE) consumption in the production of the product under consideration, taking into account the entire production chain, i.e. all background processes that directly or indirectly participate in the production, and as such makes a useful energy indicator for evaluating the results of LCA analysis (Rohrlich et al. 2000) which is quantitative, and captures all energy flows affecting the life cycle (Huijbregts et al. 2006). Because of this, CED can be used as an indicator for choosing a more environmentally friendly alternative (Penny et al. 2013) and as an energy indicator for evaluating the results of overall LCA analysis (Rohrlich et al. 2000), making it an appropriate decision-making tool.

CED has been previously used in a wide range of different environmental sustainability analyses, but in very few papers for assessment of WMS. In the WM field, the CED was used to compare different alternatives for easier decision-making in industrial WM (Puig et al. 2013), where the energy consumption of the material recovery chain and its energy recovery system (through an industrial waste incinerator), as well as generated energy savings due to avoiding of the new primary material production, were analysed. Regarding municipal waste management, Kaufman et al. (2010) developed a CED-based one-way energy comparison method that compares the analysed solution with the best possible recovery solution for each material separately, but no overall system sustainability indicator is given. CED based framework was also used for assessing the influence of different WM tactics on the sustainability of recycled materials (Tomić and Schneider 2018), but the focus was put on sustainability in a context of actual legislation goals which favour material recovery, thus results focus on material recycling sustainability and do not give an overall overview of waste management systems sustainability. CED results were also reported as a part of overall LCA, such as in the research of Giugliano et al. (2011) where alternative waste management scenarios were compared, but this way set of different sustainability indicators is obtained which are not so suitable for understandable presentation to decision-makers. Also, there are publications that analyse other, not widely accepted, technologies, with alternative fuel production (Giuliano et al. 2020, Chanthakett et al. 2021), but these analyses are then focused only on these types of technologies or compare results only with landfilling. 
Regarding the economic sustainability of WM, it has been previously analysed in numerous publications when different parts of MSW management have been looked upon, e.g. one type of facility (Colvero et al. 2020, Medina-Mijangos and Seguí-Amórtegui 2021), or one type of waste (Schneider et al. 2021, de Brito et al. 2021). Also, Luz et al. (2015) conducted a technoeconomic analysis of MSW energy recovery via gasification, and Ramos et al. (2020) conducted reported life cycle cost (LCC) results of plasma gasification, but in previous analyses of alternative treatment technologies, either analysis of specific waste fraction is reported, either, like in mentioned analyses, comparison of analysed technology with most common alternative is given. When looking for recent overall MSW management system analyses, number of publications is significantly lower. Chifari et al. (2017) carried out a complete economic analysis of Japan's WMS, where the emphasis was placed on assessing the impact of household waste separation and not the performance of the WMS. The influence of the economy of scale on total WMS cost was estimated by Bel and Fageda (2010), while the analysis of economic parameters of WM technologies is presented by Aleluia and Ferrão (2017). While these researches analyse important segments of WMS, they do not give a picture of the economic sustainability of entire WMS. Some of the influences which need to be taken into account to give an entire economic sustainability picture are the impacts of legislative, social and market changes over time, which are analysed by Tomić et al. (2017), but in this research, only analysis of one type of energy recovery plants is analysed. Step forward in this approach is made by Tomić and Schneider (2020), where the focus is put on modelling all most important influencing factors (like legislation, economic and socially influenced changes changes) and their impacts on entire WMS, but in it, the focus is also put only on analysing systems made of widely adopted technologies.

Also, there is a relatively small number of publications that combine economic and environmental assessments which are two of the most important areas when decision-making on the municipality or country-level is concerned. This is especially the case when the management of the entire collected MSW is looked upon, like LCA, which importance as an environmental assessment tool was previously emphasised, is usually performed with different scope, boundaries, timeframe, and assumptions compared to economic assessments (Norris 2001). Zhang et al. (2020) coupled LCA with economic analysis in WM, but analysis encompasses only PET bottle recycling. Life cycle environmental and economic analysis was also conducted by Koido et al. (2018), but it was made not only for one waste type, but also for one specific use - food-waste biogas production with digestate nutrient management. LCA based integrated environmental and economic analysis of wider MSW management was conducted by Xocaira Paes et al. (2020), but, as well as in many LCA based analyses, many different indicators which are obtained as results can be overvaluing for decision-making, and by using normalisation, the physical meaning of result is lost as well as the purpose of conducting all-inclusive LCA. On the other hand, there are also other publications that focus on simpler, decision-making-oriented analyses. Thus, Franchetti (2013) analysed food waste management from the perspective of carbon emissions and the economy, but here only one technology is looked upon - Anaerobic Digestion (AD). On the other hand, Jadhao (2017) used exergy analysis and cost analysis to compared three different MSW treatment options, but considered technologies are not analysed as a part of integral WMS. A step in the right direction is made by Den Boer et.al. $(2005,2007)$ which next to streamlined LCA, for conducting environmental analysis of the analysed systems, also tracked economic and social sustainability. On the other hand, the authors of the last mention publication made a very closed model with a limited number of technologies and possible configurations, while also the final result, by which technologies are compared, does not have a physical meaning. 
There are other publications that are based on multicriteria analyses like analysis conducted by Iacovidou and Voulvoulis (2018) who showed results of multi-criteria sustainability assessment framework on a case of two food waste management options in the UK region. Boffardi et al. (2021) used a multi-objective optimization model as a support tool in policy-making. The analytic hierarchy process (AHP) method was used by Milutinović et al. (2014) to rank possible MSW management alternatives in the City of Niš, Serbia, WMS, and Vučijak et al. (2016) where it is used for decision-making on the level of WMS of the Bosnia and Hercegovina. A recent review paper by Vlachokostas et al. (2021) shows that there is an increasing trend of publication of researches based on multicriteria analyses in WM, especially in the field of energy recovery of waste, and that in the last eight years socio-political criteria is increasingly included in those kinds of analyses. It can be seen that in the majority of cases are multiplecriteria decision-making (MCDM) analyses or multiple-criteria decision analyses (MCDA) which are used for ranking of alternative scenarios, and results of these analyses also do not have physical meaning, i.e. can be used only for ranking. Also, these kinds of rankings are very dependent on used weighting factors for indicators, defining which can be questionable. It is interesting to see that all these analyses that cover environmental and economic sustainability either analyse systems at one point in time or take into account longer periods but neglect timedependent trends since they ultimately strive to make the decision-making process simpler by giving unequivocal results.

It can be seen that questions of environmental and economic sustainability are the most important ones for decision-makers to choose the right path towards meeting legislative defined goals, which are at the same time sustainable from the standpoint of the citizens, as they are at the same time WMS users and its financiers, through the payment of waste management fee. This is the most pronounced in new EU member states, as well as in candidate countries, as they need to implement the biggest changes in their WMS to follow the EU WM goals and reach legislation requirements, but at the same time, their economy is less developed than those of the older EU member states. This means that economic sustainability needs to be looked upon as at least an equally important parameter as environmental sustainability. This is also important from the decision-makers' point of view as they are elected by those same system users, i.e. citizens, which finance WMS operation. Because of all of this, the WM problem is not only an environmental but also an economic and social problem at the same time.

Researchers have identified these problems and thus there are many publications covering economic or environmental sustainability in the WM, but when combined assessments, which cover the problem of sustainability of overall MSW management, are looked upon, a number of publications is much lower. From the conducted literature review, it can be seen that the majority of published researches that cover environmental, economic, and/or socio-economic sides of MSW management are made with a goal of independent analysis and comparison of obtained values for each analysed indicator or with a goal of enabling multicriterial ranking of different scenarios where presented results can be only interpreted in the scope of other presented alternatives as they do not have a meaningful physical significance which can be represented to decision-makers.

Also, no research is found which implemented environmentally-economic analysis that tracks changes in overall sustainability over time. This is important for long-range planning as solutions that can sustainably solve actual problems can become less sustainable with time, as different influencing factors change input assumptions. At the same time, analyses that take into account time-dependent changes but give single-score output, even though their results can 
show overall sustainability of the assessed system over the analysed period, their results neglect time-dependent developments, and excellent short-term results can mask poor/unsustainable long term trends. Thus, the current perception of the sustainability of the analysed system can significantly change with time, and this possible change needs to be taken into account when making an informed decision, and, as it can be seen from the presented legislation review, legislation changes are one of the biggest sources of potential changes in the WMS.

Taking into account all identified gaps in previous research, as well as identified advantages of the use of CED and the importance of economic assessment in WM decision-making, the hypothesis of this research is defined as: Economic and CED analyses of the WMS can be combined to analyse the impact of expected changes in WM legislation on the current perception of the used/planned WM technologies/systems. Also, based on a defined hypothesis, the following, main, research question can be formed: What is the impact of the imposed legislative changes on the sustainability of certain MSW management solutions in relation to their current sustainability perception?

CED is identified as a useful single score indicator for evaluating the results of overall LCA analysis, which is found to be a go-to approach to environmental sustainability assessment of WMS which combines material and energy recovery of waste materials. As for its calculation, LCA-like system modelling is used, it could be easily extended with economical flowdependent cost/income functions. As results of these two analyses are obtained from the same model, they can be combined to give a single score indicator - the Economic Efficiency of Resource Recovery (EERR) Index. EERR index has a physical meaning and represents system cost per percentage of recovered resources, which makes obtained results easier to understand and present to decision-makers. This represents one of the contributions of this research when compared to the previous publications which gave an independent comparison of sustainability of analysed systems by each analysed indicator, or overall single score indicator/ranking that do not have meaningful physical significance.

As this question of environmentally-economical sustainability is of most importance for new EU member states and candidate countries that have a long way to meet EU legislation goals, it is important to track how the economic and environmental sustainability of the analysed systems changes as different legislation goals are met, and compare them to the starting point. In this research, this is done by tracking environmentally-economical sustainability correlation, i.e. EERR index values, in dependence on legislation imposed changes. By this, step forward from previous research is done, as literature review didn't find research which analyses not only overall sustainability of different WMS, but also under different conditions, which heavily influence and change input parameters of the analysis, and, thus, all corresponding energy and mass flows. Also, presented visual representation of sustainability makes another step forward in making scientific results more comparable, understandable, and presentable to decisionmakers. Results of this part of the research will directly give an answer to the presented main research question.

Obtained results can significantly change the perceptions of sustainability of different technologies which people usually generate from their point of view and are based on actual (today) situation. In this paper, defined index, obtained results, and presented graphical representation, can be a valuable tool for decision-makers especially in new member states which lag behind EU WM targets, and in EU candidate countries that need to plan their decisions by taking into account long term EU goals. This new view on the sustainability of WM can help new member states to make quality decisions faster which is in line EU Circular 
Economy Action Plan and its main idea to gradually equalize the level of best practice across the EU Member States

\section{MATERIALS AND METHODS}

In order for the WMS to be analysed from the environmental and economic aspects, it is necessary to define what exactly analysis encompasses, which systems are covered as well as which models are used.

\section{System definition}

The boundaries of the system are set to cover the entire municipal WMS, from municipal waste collection, thorough separation, treatment, disposal, and production of secondary materials, on the material recovery side, as well as energy, on the energy recovery side. To analyse only the WM process, it is isolated in the way that waste streams (mixed and separately collected wastes) cross-analysis boundary as a burden-free, so system analysis can be defined as cradle-to-grave where produced waste material is disposed of or it can be recovered.

Manufactured materials and energy products are valued through market activities, which are for the environmental analysis defined by the used Ecoinvent Centre (2016) LCA database, while for the economic analysis through market prices of the considered products. As for the timeframe, the analyses use annual input data, so the obtained results describe one year of system operation. All input material and energy flows, except input waste flows, carry corresponding burdens, i.e. environmental and/or economic burden as a result of required production and distribution operations and/or markets. Concerning output streams, waste streams that are not classified as municipal waste, and therefore are not disposed of within the system under consideration, represent an environmental and/or economic burden following the needs of external technologies for its treatment and disposal.

In this research individual technologies that are an integral part of the system are identified, which enabled monitoring of energy and material inputs and outputs of particular technologies. The material and energy flows of the considered technologies are modelled mostly on the basis of data from LCI databases (Ecoinvent (Ecoinvent Centre 2016) and NREL USLCI (NREL, 2016)), while modelling of a smaller number of technologies is based on the literature data. Ecoinvent database is complete as the data provider for each dataset allows and ecomaps all known data, thus, it does not have quantitative cut-off criteria (Weidema et al. 2013). Regarding the USLCA database, it incorporates the rule to include a minimum of $95 \%$ of all input materials and energy in its data sets (Athena Sustainable Materials Institute 2004). In this research, the Ecoinvent principle is adopted, all unnecessary exclusions are avoided, and all available process data are incorporated in the used inventory dataset. Next to used datasets from LCA databases, biogas (Mechanical and Biological Treatment (MBT)) plant input-output dataset is modelled based on literature data (McDougall et al. 2001), as well as waste gasification plant (Haig 2018, Ardolino 2018), plant for waste incineration using real plant data (Energinet.dk 2012), and the regulated landfill (with landfill gas collection system) through the use of Environmental Protection Agency (USEPA AP-42) data (USEPA 2019).

Regarding the economy, economic calculations were done using calculated input/output flow data and input dependent economic function which were adapted from the literature. Thus, economic functions for composting facility and landfill were adapted from Minoglou and Komilis (2013) research, for MBT and material recovery facility from McDougall et al. (2001), 
AD facility from Minoglou and Komilis (2013), WtE plant from Tomić et al. (2016) and gasification plant from McDougall et al. (2011) and Ducharme (2010) research. All adapted economic functions are shown in Table 1, where they are expressed as presented or, if in original research dataset for more plants of different sizes is presented, a least-squares regression analysis is carried out and function, in a form with the best correlation with the obtained dataset (the smallest Pearsons product-moment correlation coefficient), is reported. As it can be seen, obtained economic functions follow economy of scale, and thus obtained functions that present absolute costs have positive, and functions that present specific costs (per tonne of input waste stream) have negative values in exponents.

Table 1. Economic functions

\begin{tabular}{lllc}
\hline Technology & Investment cost & Operating costs & Equation \\
\hline Composting & $i=2000 x^{\wedge}(0.80)[€]$ & $o=2000 x^{\wedge}(-0.50)[€ / \mathrm{t}]$ & $(1),(2)$ \\
Landfill & $i=3500 x^{\wedge}(0.70)[€]$ & $o=150 x^{\wedge}(-0.30)[€ / t]$ & $(3),(4)$ \\
Biogas plant & $i=26194 x^{\wedge}(0.6)[€]$ & $o=12723 x^{\wedge}(-0.6)[€ / t]$ & $(5),(6)$ \\
Incineration plant & $i=573.30 x+2 \times 10^{\wedge} 7[€]$ & $o=51.60 x[€]$ & $(7),(8)$ \\
Secondary separation & $i=23844 x^{\wedge}(-0.404)[€ / \mathrm{t}]$ & $o=3353.10 x^{\wedge}(-0.404)[€ / \mathrm{t}]$ & $(9),(10)$ \\
Gasification plant & $i=2135.200 x^{\wedge}(0.93)[€]$ & $o=240.570 x^{\wedge}(0.87)[€]$ & $(11),(12)$ \\
Material recovery & \multicolumn{2}{c}{$c=51515 x^{0.73}[€]^{*}$} & $(13)$ \\
\hline i- investment cost, o- operation and maintenance costs, c- overall cost, $\mathrm{x}-$ input waste stream $[\mathrm{t} / \mathrm{y}]$ & \\
* due to small investment cost can be built as distributed facilities, thus overall cost is tracked & \\
\hline
\end{tabular}

Regarding the analysed time frame, the analysis describes one year of operation by using annual input/output data. Also, through the addition of economic functions dependant on input flows, yearly economic analysis is conducted. To track the consequence of the implementation of EU goals, 2013 is defined as the starting point of the analysis which represents the situation before entering the EU and those results are compared to results of the same systems in the conditions when EU waste legislation goals for 2020 and 2030 are met. To do that, collected waste fractions were prognosed using LCA-IWM prognostic software (den Boer 2005), taking into account time and legislation-dependent changes. The used model reduces the prediction error by taking into account a wide range of socio-economic parameters, such as population number, household size, life expectancy, labour employed in agriculture, age distribution, gross domestic product, legislation goals, etc.

\section{Description of models}

CED values of analysed systems are calculated in a way that all calculated material and energy flows entering/exiting analysed system are recalculated to primary energy equivalents using CED values for corresponding material. In the majority of cases, the CED value for corresponding market activity is used, thus, the results of the analysis are not strictly dependent on a specific case. Because of reducing material and energy flows to universal energy equivalent, overall CED result represent single-score metrics for environmental sustainability comparison, where positive results represent primary energy drain (i.e. additional raw material extraction from nature is needed), while negative represents an energy return (i.e. raw material extraction from nature is reduced), in a comparison with an existing (usual) way of providing the same raw materials and/or energy vectors.

The used method of impact allocation is the system extension method, which implies that the impacts associated with the WM activities are taken into account by comparing their production with the avoided impacts of the production of the same raw materials from the existing market. How beneficial the impact of avoided production is, depends on the existing energy mix used in the production of the product it replaces, which is defined by linking the system's input and output flows to local markets. 
CED results display overall primary energy balance, taking into account all primary energy drains (needed for system operation) and savings (due to material and energy production) and display results in the measure of energy - Joules. While this result can be used for the comparison of WMS, it would be better to compare system efficiency (Tomić and Schneider 2017). This is done by dividing the overall CED result (i.e. the value of recovered primary energy) of the analysed system with CED (i.e. embodied energy) of materials in waste streams that are entering analysed system. Calculated results represent a percentage of recovered primary energy that was embodied in the collected waste streams - Recovery of Embodied Energy (REE) (Equation 14). In this calculation, bio-waste is not valuated on the input side due to the inability of its substitution/valuation, while material products gained from bio-waste (i.e. compost) are valuated as a replacement for fertilizers (by its nitrogen, phosphate, potassium (NPK) values) (ISWA 2015) and their intrinsic energy (Gilbert 2009).

Regarding the economic analysis, results of economic cash flow analysis usually show the overall cost of the system that needs to be covered, or generated income. The WMS provides a public service of waste collection/management and is financed by citizens through WM fees, thus, the economic results of a system have an influence on its amount. The WM fee is usually charged per ton of collected mixed waste from each user, thus, in this research overall system cost is divided by the amount of collected mixed waste by which Specific System Cost (SSC) is calculated (Equation 15). By doing this influence of legislation influenced changes on the WM fee is analysed. As this is a comparative analysis, the economy of the waste collection is not tracked as all generated waste need to be collected anyway and collection quantity is the same across all analysed systems, i.e. it does not generate a difference in the final results.

Economic functions define the system's expenses while incomes are generated through the markets i.e. sales of produced secondary raw materials and energy vectors. WM fee usually covers the difference between income and expenses. In this paper, the minimum WM fee is tracked which is needed to equalize systems expenses and incomes. This means that all revenues (from produced energy vectors, secondary materials, and compost) and expenditures (investment and operating and maintenance costs) of such a system are taken into account, and the system operates at a positive zero. Thus, reducing the overall cost results in a reduced fee for the citizens.

Separate environmental and economic analysis done through calculation of embodied energy recovery and specific system cost, while answering two questions, they do not give a picture of overall sustainability. The best way how to measure something is with a single score parameter. Because of which a single score Economic Efficiency of Resource Recovery (EERR) index is defined by dividing Specific System Cost (SCC) with Recovery of Embodied Energy (REE) Equation 16. This index shows a specific system cost for achieving resource recovery. The calculation of the EERR index is outlined by equations 14 to 16 .

$$
\begin{gathered}
S C C[€ / t]=\frac{\text { Overall system cost }[€]}{\text { Quantitiy of mixed waste }[t]} \\
R E E[\%]=\frac{C E D \text { of waste managament system }[M J]}{C E D \text { of collected waste materials }[M J]} \times 100 \\
E E R R[€ / \text { t per } \%]=\frac{S C C[€ / t]}{R E E[\%]}
\end{gathered}
$$




\section{Description of case}

To analyse the influence of legislation on the environmental and economic sustainability of WMS, analysis is conducted on the case of the City of Zagreb, as it is the capital city of the Croatia, newest EU member state which became an EU member mid-2013, and since then struggle to meet EU WM legislation goals (Luttenberger 2020). Because of this, the situation in 2013 is taken as a referent point of the analysis. All analysed systems are defined for referent year and their behaviour is tracked as legislation goals are met. Thus, two more key points are taken into consideration, which are defined by two of the most challenging checkpoint regarding meeting legislation goals and define the situation in 2020 and 2030. The situation regarding waste quantity and composition is prognosed using the LCA-IWM Waste Prognostic Tool (den Boer 2007), and the cost of the system for system users as well as CED values were calculated for the same systems in different circumstances - circumstances that can be expected in near future. Thus, 2020 and 2030 do not strictly represent years in the context of time but the situation in the systems when legislative requirements for those years are met. Through this, the environmental and economic performance of analysed systems can be assessed in the context of expected changes which is important for WMS planning.

The referent point is described with the overall collection of 268,754 t of MSW. Separately collected is $13.46 \%$ from which $11.80 \%$ is achieved through a separate collection of bio-waste (AZO 2014) - Table 2. The composition of mixed waste is presented in Table 3.

Table 2. Waste quantities

\begin{tabular}{|c|c|c|c|c|c|c|}
\hline & \multicolumn{2}{|c|}{$2013^{1}$} & \multicolumn{2}{|c|}{$2020^{2}$} & \multicolumn{2}{|c|}{$2030^{2}$} \\
\hline & Quantity [t] & $\begin{array}{c}\text { Quantity } \\
{[\mathrm{kg} / \text { capita }]}\end{array}$ & Quantity [t] & $\begin{array}{c}\text { Quantity } \\
\text { [kg/capita] }\end{array}$ & Quantity [t] & $\begin{array}{c}\text { Quantity } \\
\text { [kg/capita] }\end{array}$ \\
\hline Glass waste & 818 & 1.03 & 5500 & 6.96 & 9,300 & 11.77 \\
\hline Fe waste & 447 & 0.57 & 1,520 & 1.92 & 2,146 & 2.72 \\
\hline Al waste & 53 & 0.07 & 180 & 0.23 & 254 & 0.32 \\
\hline Paper waste & 1447 & 1.83 & 59,700 & 75.57 & 82,200 & 104.05 \\
\hline Plastic waste (PE) & 381 & 0.48 & 8,565 & 10.84 & 14,837 & 18.78 \\
\hline Plastic waste (PET) & 1,314 & 1.66 & 29,535 & 37.39 & 51,163 & 64.76 \\
\hline Garden waste & 27,935 & 35.36 & 28,630 & 36.24 & 28,808 & 36.47 \\
\hline Kitchen waste & 3,773 & 4.78 & 78,570 & 99.46 & 104,792 & 132.65 \\
\hline Mixed municipal waste & 232,587 & 294.41 & 108,300 & 137.09 & 123,600 & 156.46 \\
\hline Overall & 268,755 & 340.20 & 320,500 & 405.70 & 417,100 & 527.97 \\
\hline
\end{tabular}

As can be seen, to be able to meet EU legislation goals, the efficiency of primary separation of waste needs to greatly improve (Table 2 ), which also has a significant influence on mixed waste composition (Table 3).

Table 3. Mixed waste composition

\begin{tabular}{|c|c|c|c|c|c|c|}
\hline & \multicolumn{2}{|c|}{$2013^{1}$} & \multicolumn{2}{|c|}{$2020^{2}$} & \multicolumn{2}{|c|}{$2030^{2}$} \\
\hline & Share [\%] & Quantity [t] & Share [\%] & Quantity [t] & Share [\%] & Quantity [t] \\
\hline Paper waste & 27.1 & 63,031 & 18.4 & 19,927 & 22.2 & 27,439 \\
\hline Plastics waste & 26.4 & 61,403 & 35.3 & 38,230 & 28.8 & 35,597 \\
\hline Metal waste & 1.1 & 2,558 & 1.5 & 1,625 & 1.1 & 1,360 \\
\hline Glass waste & 3.6 & 8,373 & 5.1 & 5,523 & 4.1 & 5,068 \\
\hline Garden waste & 5.1 & 11,862 & 2.3 & 2,491 & 2.5 & 3,090 \\
\hline
\end{tabular}




\begin{tabular}{l|cc|cc:cc} 
Bio-waste & 26.5 & 61,636 & 12.1 & 13,104 & 13.7 & 16,933 \\
Other waste & 10.2 & 23,724 & 25.4 & 27,508 & 27.7 & 34,237 \\
\hline 1 based on local WM plan (Mužinić et al., 2014) \\
2 prognosed data (den Boer 2007) \\
\hline
\end{tabular}

\section{Analysed systems}

To analyse the influence of legislation, the economic and environmental efficiency of different WMS is assessed.

The first analysed system is Landfill based system (Figure 1a) which does not have any sort of secondary separation of mixed waste. Separately collected bio-waste is composted and separately collected recyclable materials are treated (separated) in the Material recovery facility and sold on the secondary material market. Only energy recovery is implemented in the form of landfill gas collection. The described system was implemented in the case study city in a referent year. Analysed systems are named by final (residual waste) treatment facilities.

As can be seen, three different waste streams are tracked - bio-waste, mixed waste and recyclables. Recovery of separately collected recyclable materials is not changing with analysed scenarios so possible changes in the structure of that part of a WM chain are not analysed. Nevertheless, the material recovery chain of recyclable materials is shown in a simplified form as it interacts with mixed and bio-waste recovery chains and influences final results. Thus, recyclable materials from the secondary separation of mixed waste increase the input waste streams in Material Recovery Facilities (MRF), while residual waste which can be classified as MSW is treated in a mixed municipal waste treatment chain. 

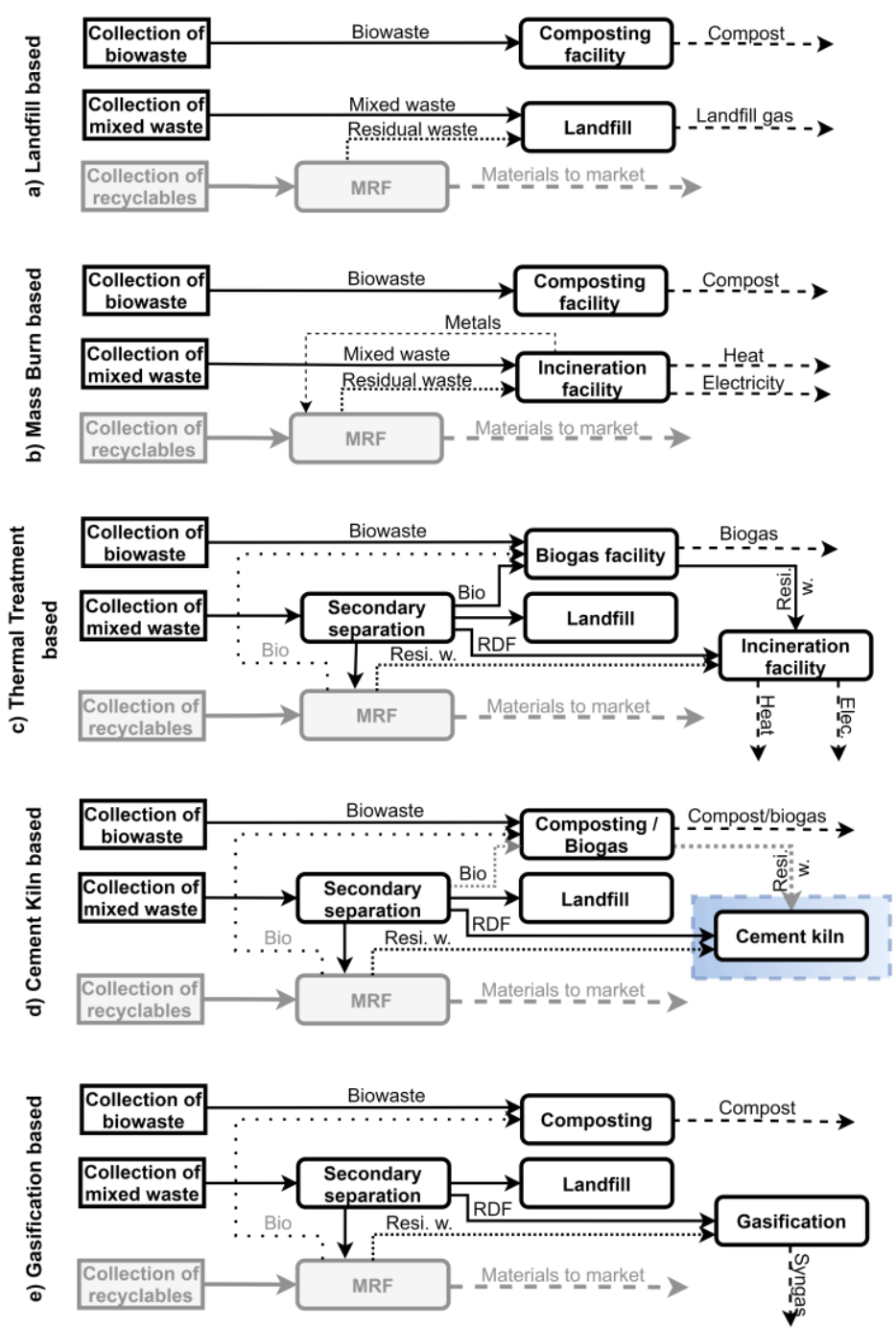

Figure 1. Analysed systems

One of the most common ways to solve the problem of excessive waste landfilling is its thermal treatment, i.e. incineration, in a form of mass burn of a mixed waste fraction. Integration of this technology in this way is a simple and quick solution as no other WM technology needs to be implemented in comparison with the Landfill based system. This solution is shown in Figure $1 \mathrm{~b}$ as the Mass Burn system. This system can increase energy recovery through electricity and heat production but also increases material recovery by separating metals from input waste before its incineration.

Other systems are more complicated and encompass the secondary separation of mixed waste. Secondary separation technologies separate recyclable fractions, as well as bio-waste, which are separately treated, while the residual burnable waste in a form of Refuse Derived Fuel (RDF) is thermally treated. The system can be also configured to boost energy recovery by the introduction of a local waste incineration facility and biogas facility. This is the case in the Thermal treatment based system - Figure 1c. In this case, paper is not separated for material recovery as it is too contaminated, and plastic is also kept as a part of the RDF stream to boost energy recovery.

The Cement kiln based system (Figure 1d) avoids investing in dedicated energy recovery plants and outsource treatment of residual waste, so it is treated in cement kiln, while bio-waste is 
composted. Separated bio-waste from mixed waste after composting stage (which is usually called bio-stabilisation) is not sold because of contaminations and is landfilled, while separated recyclables are further materially recovered. Another configuration of this system exchanges composting with biogas plant (Cement kiln with $A D$ ). Even though cement kiln does not produce an energy vector as a product of energy recovery, incinerated RDF reduces the consumption of primary fuel (coal) in the equivalent of its energy value, and its influence on resource recovery is valuated as a reduction in primary energy consumption equivalent for substituted primary fuel. As cement kiln is not part of the local WMS, system users need to pay for its service of thermal treatment of residual waste, so in Figure 1 it is visually separated from the rest of the analysed system.

The last scenario introduces not-so-common technology in the field of MSW management gasification. This thermochemical conversion technology produces syngas which can be used for electricity generation or can be further transformed into other marketable products. This system is based on the Thermal Treatment based system where a cement kiln is replaced with a waste gasification plant and an AD plant with composting plant. Also, this technology represents a more socially acceptable energy recovery solution because waste is not incinerated and there is no negative connotation around gasification technology like it is around waste incineration.

Produced/recovered material flows from the waste separation and recovery technologies represent the material output from the municipal WMS and are entering the secondary raw materials market. Income from material sales is calculated from market price indicators for the collected material (Table 4) and the calculated amount of materials placed on the secondary raw materials market.

Table 4. Material prices

\begin{tabular}{lc}
\hline Material & Price $[€ / \mathrm{t}]^{*}$ \\
\hline Glass & 10.10 \\
Paper & 39.28 \\
Aluminium & 1133.44 \\
Steel & 131.86 \\
PET & 50.79 \\
HDPE & 32.54 \\
Compost & 26.97 \\
\hline * based data from Letsrecycle (2018) for January 2018 \\
\hline
\end{tabular}

The selling price of electricity is modelled for referent point on the basis of the local Tariff system for electricity from renewable energy sources and cogeneration (Government of the Republic of Croatia 2013) and amounts to $73.6 € / \mathrm{MWh}$ for electricity from CHP and 158 $€ / \mathrm{MWh}$ for electricity from a biogas cogeneration plant. Regarding the produced heat, the selling price of the heat was calculated based on the local heat distributor and amounts to 34 $€ / \mathrm{MWh}$ (HEP 2019). The cost of outsourcing of RDF thermal treatment in cement kilns ranges from 40 to $50 € / t$ in the peak of demand [Government of India 2018, RPS 2014], while it usually ranges between -20 and $+20 € / t$ (Schäfer and Moser 2012) Replacement of main fuel (coal) in cement kilns with RDF enables savings for the operator of up to $50 € / \mathrm{t}$, so negative price makes sense (EcoMondis 2018). From these data, the price of $40 € / t$ is modelled and used in this analysis, which describes a situation when a municipality pays for the treatment of such waste. 


\section{RESULTS AND DISCUSSION}

Using LCA-based system models, material and energy flows of each analysed system are tracked which enabled the conducting of economic analysis, next to an environmental one. Figure 2 shows the material recovery of each analysed scenario. When compost production is not looked upon, the biggest material recovery is in scenarios with secondary waste separation, and the smallest is in Landfill based system. There is the biggest production of secondary plastic and glass, while quantities of other materials represent under $10 \%$ of material production in total. Regarding compost production, it is the same across all scenarios because it is produced only from primary separated waste.

Material recovery increases as waste legislation goals are met, thus, it is the smallest in the referent point, i.e. 2013. The biggest increase is in the systems which completely depend on primary waste separation to boost material recovery, i.e. Landfill based system, while also Incineration based system is a close second.

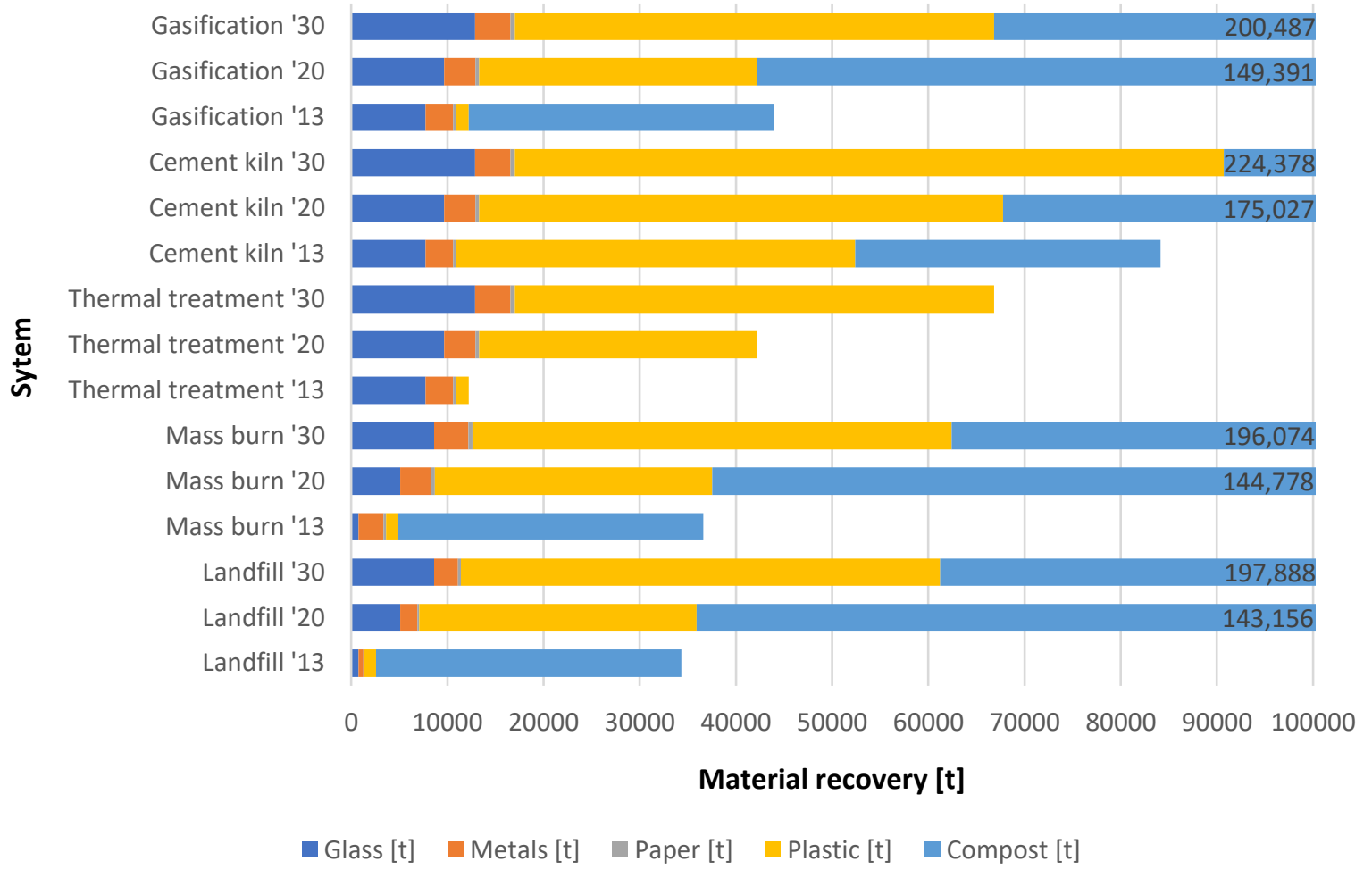

Figure 2. Material recovery quantities

The results of energy recovery are shown in Table 5. Energy production is connected to the generation/production of residual waste and bio-waste fractions. While products of thermal treatment are directly used for covering final consumption, bio-waste, landfill gas and syngas are usually transformed into other forms before final consumption.

Table 5. Energy recovery

\begin{tabular}{ccccc}
\hline System / Energy carrier & $\begin{array}{c}\text { Biogas / } \\
\text { Landfill gas } \\
\left(10^{6} \mathrm{Nm}^{3}\right)\end{array}$ & $\begin{array}{c}\text { Electricity } \\
(\mathrm{GWh})\end{array}$ & $\begin{array}{c}\text { Heat } \\
(\mathrm{TJ})\end{array}$ & $\begin{array}{c}\text { Syngas } \\
\left(10^{6} \mathrm{~kg}\right)\end{array}$ \\
\hline Landfill '13 & 21.25 & 0.00 & 0.00 & 0.00 \\
Landfill '20 & 8.62 & 0.00 & 0.00 & 0.00
\end{tabular}




\begin{tabular}{ccccc} 
Landfill '30 & 12.26 & 0.00 & 0.00 & 0.00 \\
Mass burn '13 & 0.00 & 89.87 & $1,440.38$ & 0.00 \\
Mass burn '20 & 0.00 & 71.40 & $1,144.35$ & 0.00 \\
Mass burn '30 & 0.00 & 79.82 & $1,417.98$ & 0.00 \\
Thermal treatment '13 & 14.78 & 81.65 & $1,308.54$ & 0.00 \\
Thermal treatment '20 & 20.33 & 70.16 & $1,094.86$ & 0.00 \\
Thermal treatment '30 & 24.81 & 74.35 & $1,155.61$ & 0.00 \\
Cement kiln w. AD '13 & 14.78 & 0.00 & 0.00 & 0.00 \\
Cement kiln w. AD '20 & 20.33 & 0.00 & 0.00 & 0.00 \\
Cement kiln w. AD '30 & 24.81 & 0.00 & 0.00 & 0.00 \\
Gasification '13 & 0.00 & 0.00 & 0.00 & 197.70 \\
Gasification '20 & 0.00 & 0.00 & 0.00 & 169.43 \\
Gasification '30 & 0.00 & 0.00 & 0.00 & 190.36 \\
\hline
\end{tabular}

In this case, biogas/landfill gas production is transformed into four different energy vectors: to heat and electricity using combined heat and power (CHP) internal combustion engine, biomethane (BM) using biogas upgrade plant (water absorption based technology), and compressed natural gas $(\mathrm{CNG})$ using $\mathrm{CNG}$ plant. Economic functions of these technologies are modelled based on literature data for different technologies: CHP internal combustion engine (Karellas et al. 2010), biogas upgrade plant for bio-methane production (Warren 2012) and CNG plant (Mitchell 2015) - Table 6. On the other hand, syngas production can be transformed into electricity or ethanol. Economic functions presented in Table 1 define the mostly used waste gasification system, while additional costs for production of ethanol are modelled based on literature data (US Department of Energy 2010) and also presented in Table 6. Even though it is not that common in municipal WM practices to use waste for ethanol production, while electricity can be easily generated from renewable energy sources (Saad et al. 2018), ethanol produced from waste can replace fossil fuels in the transportation sector without the need for biomass use (Yadav et al. 2020).

Table 6. Economic functions of biogas and syngas transformation technologies

\begin{tabular}{|c|c|c|c|}
\hline Technology & Investment cost & Operating costs & Equation \\
\hline \multicolumn{4}{|l|}{ Biogas transformation: } \\
\hline $\mathrm{CHP}$ & $i=415.970 y^{\wedge}(0.6)[€]$ & $o=90544 y^{\wedge}(-0.60)[€ / \mathrm{m} 3]$ & $(17),(18)$ \\
\hline Bio-methane production & $i=710.040 y+969331[€]$ & $o=317.640 y+30946[€]$ & $(19),(20)$ \\
\hline CNG production & $i=15243 z+243028[€]$ & $o=-3.249 z^{\wedge} 2+167.6 z+19442[€]$ & $(21),(22)$ \\
\hline Syngas transformation: & & & \\
\hline Ethanol production* & $i=136.289 x^{\wedge}(0.93)[€]$ & $o=15.356 x^{\wedge}(0.87)[€]$ & $(23),(24)$ \\
\hline
\end{tabular}

Using the previously described LCA model and CED LCIA data from the Ecoinvent database percentages of recovered primary energy which was embodied in the collected waste streams are calculated - Table 7. Presented results include results of analysed systems as different legislation goals are met, as well as overall results.

As can be seen from the presented results, the biggest overall resource (primary energy) recovery of $50 \%$ can be seen with the integration of gasification plant with ethanol production. Ethanol production from primary sources consumes substantial amounts of resources which results in significant primary energy consumption, thus, its substitution leads to significant resource/primary energy recovery. This can be clearly seen when compared with electricity production from the same base technology. The second biggest resource recovery of $46 \%$ was recorded when the secondary separation of mixed waste is combined with biogas plant while a majority of residual waste treatment is outsourced in a cement kiln, which is a more conventional approach. Also, it can be seen that all analysed systems achieve significantly better results concerning environmental sustainability and, on average, double resource 
recovery when compared to a landfill based. When biogas transformations are looked upon, cogeneration of heat and electricity shows the best results.

Table 7. Recovery of embodied energy

\begin{tabular}{lccccc}
\hline System & $\begin{array}{c}\text { Biogas/syngas } \\
\text { use: }\end{array}$ & $\begin{array}{c}2013 \\
{[\%]}\end{array}$ & $\begin{array}{c}2020 \\
{[\%]}\end{array}$ & $\begin{array}{c}2030 \\
{[\%]}\end{array}$ & $\begin{array}{c}\text { Average } \\
{[\%]}\end{array}$ \\
\hline 1) L & CHP & 7.66 & 26.41 & 30.95 & 21.66 \\
1) L & BM & 6.88 & 26.17 & 30.70 & 21.25 \\
1) L & CNG & 6.00 & 25.87 & 30.38 & 20.75 \\
2) MB & & 36.85 & 41.52 & 43.35 & 40.58 \\
3) TT & CHP & 36.53 & 43.49 & 44.68 & 43.07 \\
3) TT & BM & 35.82 & 42.69 & 43.89 & 42.3 \\
3) TT & CNG & 35.07 & 41.90 & 43.15 & 41.54 \\
4) CK & & 35.97 & 43.21 & 43.97 & 41.05 \\
4) CKwAD & CHP & 41.09 & 48.89 & 49.37 & 46.45 \\
4) CKwAD & BM & 41.16 & 48.33 & 48.78 & 46.09 \\
4) CKwAD & CNG & 40.41 & 47.54 & 48.04 & 45.33 \\
5) G & EL & 26.61 & 35.05 & 36.74 & 32.80 \\
5) G & ET & 47.51 & 51.10 & 51.74 & 50.11 \\
\hline L- Landfill; MB - Mass burn; TT - Thermal Treatment; CK - Cement kiln; CKwAD - \\
Cement kiln with AD; G - Gasification; BM - Bio-methane; EL - Electricity; ET - \\
Ethanol
\end{tabular}

Resource recovery is boosted through material and energy recovery/production, but increasing system complexity (by the integration of new technologies) also boosts internal material and energy consumption of the system which counterbalances part of the positive influence. Thus, the best results are achieved through primary waste separation for which no additional resources are needed, while secondary separation requires additional resource consumption. Through the comparison of the results of the fourth system with a composting facility (Cement kiln) and with a biogas facility (Cement kiln with $A D$ ), it can be seen that the composting facility use more primary energy than compost is worth through its NPK equivalent, and thus solution with biogas plant gives better results. The biggest influence on resource recovery has the resource intensity of the primary product which is replaced through the recovery, thus material recovery has a bigger influence on boosting resource recovery share, i.e. influence on environmental sustainability. This can also be seen when comparing gasification-based scenarios (Gasification) with electricity and ethanol production, where much bigger embodied energy is associated with replaced ethanol production than with electricity.

Regarding overall system cost (Table 8), the results of analysed systems are not so simply comparable to the landfill-based system. All scenarios require an increase in WM fee compared to landfill-based one, but Cement kiln based one with the integration of anaerobic digestion requires the smallest increase. It can be noticed that the integration of a dedicated (local) thermal treatment facility directly (drastically) reduces the economic sustainability of the system, while the introduction of a biogas facility increases it.

Table 8. Specific system costs

\begin{tabular}{lccccc}
\hline System & $\begin{array}{c}\text { Biogas/syngas } \\
\text { use: }\end{array}$ & $\begin{array}{c}2013 \\
{[\%]}\end{array}$ & $\begin{array}{c}2020 \\
{[\%]}\end{array}$ & $\begin{array}{c}2030 \\
{[\%]}\end{array}$ & $\begin{array}{c}\text { Averag } \\
\text { e [\%] }\end{array}$ \\
\hline 1$) \mathrm{L}$ & CHP & 3.55 & 15.21 & 0.80 & 7.44 \\
$1) \mathrm{L}$ & $\mathrm{BM}$ & 16.05 & 28.01 & 15.05 & 20.64
\end{tabular}




\begin{tabular}{lccccc} 
1) $\mathrm{L}$ & $\mathrm{CNG}$ & 10.46 & 24.64 & 8.56 & 15.67 \\
2) $\mathrm{MB}$ & & 15.79 & 98.32 & 67.90 & 67.04 \\
3) $\mathrm{TT}$ & $\mathrm{CHP}$ & 49.94 & 165.66 & 126.80 & 122.92 \\
3) $\mathrm{TT}$ & $\mathrm{BM}$ & 73.20 & 229.00 & 195.19 & 177.76 \\
3) $\mathrm{TT}$ & $\mathrm{CNG}$ & 55.37 & 180.19 & 142.05 & 135.48 \\
4) $\mathrm{CK}$ & & 32.72 & 41.69 & 37.72 & 38.07 \\
4) CKwAD & $\mathrm{CHP}$ & 24.71 & 10.32 & -2.64 & 9.72 \\
4) CKwAD & $\mathrm{BM}$ & 47.97 & 73.66 & 65.80 & 64.46 \\
4) CKwAD & $\mathrm{CNG}$ & 31.76 & 29.27 & 17.47 & 26.00 \\
5) G & $\mathrm{EL}$ & 53.55 & 159.61 & 111.48 & 121.41 \\
5) G & $\mathrm{ET}$ & 35.50 & 110.04 & 66.38 & 80.03 \\
\hline L- Landfill; MB - Mass burn; TT - Thermal Treatment; CK - Cement kiln; CKwAD - \\
Cement kiln with AD; G - Gasification; BM - Bio-methane; EL - Electricity; ET - \\
Ethanol
\end{tabular}

System WM fee is reduced through material and energy recovery/production, but increasing system complexity (by the integration of new technologies) increases the cost of the system which counterbalances part of the positive influence, which is similar behaviour as when resource recovery is looked upon. Thus, primary waste separation also has a better influence on system costs than secondary waste separation. Bigger income is achieved through energy recovery than through material recovery, but thermal treatment facilities generate huge investment costs that need to be covered. Thus, the outsourcing of residual waste treatment shows better results. Biogas plants are the most preferable energy recovery option due to the low cost of technology and generate bigger income than is achievable through compost production. Regarding biogas transformation, the smallest costs are connected to direct heat and electricity production, thus, better results are achieved. Regarding gasification, a relatively small increase in investment cost is quickly paid off through ethanol production compared to electricity production.

The overall analysis in few time periods does not give an entire picture of the long-term sustainability of the WMS in the context of legislation-influenced changes. Also, a separate analysis of environmental and economic results for each legislation-defined step is not a transparent tool for comparison of long-term sustainability to referent results. Because of that, those results are aggregated and shown in Figure 3 which shows the interrelationship between environmental and economic sustainability for all considered systems.

The sustainability of each system can be shown through a single value indicator by dividing Embodied energy recovery with Specific system cost, by which the Economic Efficiency of Resource Recovery (EERR) index is calculated - Table 9. This index shows a specific cost of the system for achieving identified resource recovery and can be used to describe the overall sustainability of the considered systems, where a smaller value means greater overall sustainability.

Table 9. Economic Efficiency of Resource Recovery (EERR)

\begin{tabular}{lcccc}
\hline System & $\begin{array}{c}\text { Biogas/syngas } \\
\text { use: }\end{array}$ & $\begin{array}{c}2013 \\
{[€ / \text { per \%] }}\end{array}$ & $\begin{array}{c}2020 \\
{[€ / \text { t per \%] }}\end{array}$ & $\begin{array}{c}2030 \\
{[€ / \text { t per \%] }}\end{array}$ \\
\hline 1$) \mathrm{L}$ & $\mathrm{CHP}$ & 0.463 & 0.576 & 0.026 \\
$1) \mathrm{L}$ & $\mathrm{BM}$ & 2.333 & 1.07 & 0.49 \\
$1) \mathrm{L}$ & $\mathrm{CNG}$ & 1.743 & 0.952 & 0.282 \\
2) $\mathrm{MB}$ & & 0.428 & 2.368 & 1.566
\end{tabular}




\begin{tabular}{lcccc} 
3) $\mathrm{TT}$ & $\mathrm{CHP}$ & 1.367 & 3.809 & 2.838 \\
3) $\mathrm{TT}$ & $\mathrm{BM}$ & 2.044 & 5.364 & 4.447 \\
3) $\mathrm{TT}$ & $\mathrm{CNG}$ & 1.579 & 4.3 & 3.292 \\
4) CK & & 0.91 & 0.965 & 0.858 \\
4) CKwAD & $\mathrm{CHP}$ & 0.601 & 0.211 & -0.053 \\
4) CKwAD & $\mathrm{BM}$ & 1.165 & 1.524 & 1.349 \\
4) CKwAD & $\mathrm{CNG}$ & 0.786 & 0.616 & 0.364 \\
5) G & $\mathrm{EL}$ & 2.012 & 4.554 & 3.035 \\
5) G & $\mathrm{ET}$ & 0.747 & 2.154 & 1.283 \\
\hline L- Landfill; MB - Mass burn; TT - Thermal Treatment; CK - Cement kiln; CKwAD - \\
Cement kiln with AD; G - Gasification; BM - Bio-methane; EL - Electricity; ET - Ethanol \\
\hline
\end{tabular}

These values also can be graphically presented. As the EERR index represents the ratio between two plotted values, it represents the direction coefficient and can be represented by straight lines. In Figure 3 its values are plotted for referent points (which describe the situation for 2013) which can help to determine the overall sustainability of other results in the dependence to a referent case. To reduce the clutter, these lines are plotted only for the most commonly used variants regarding energy vector transformations, but this is enough to draw the conclusions. 


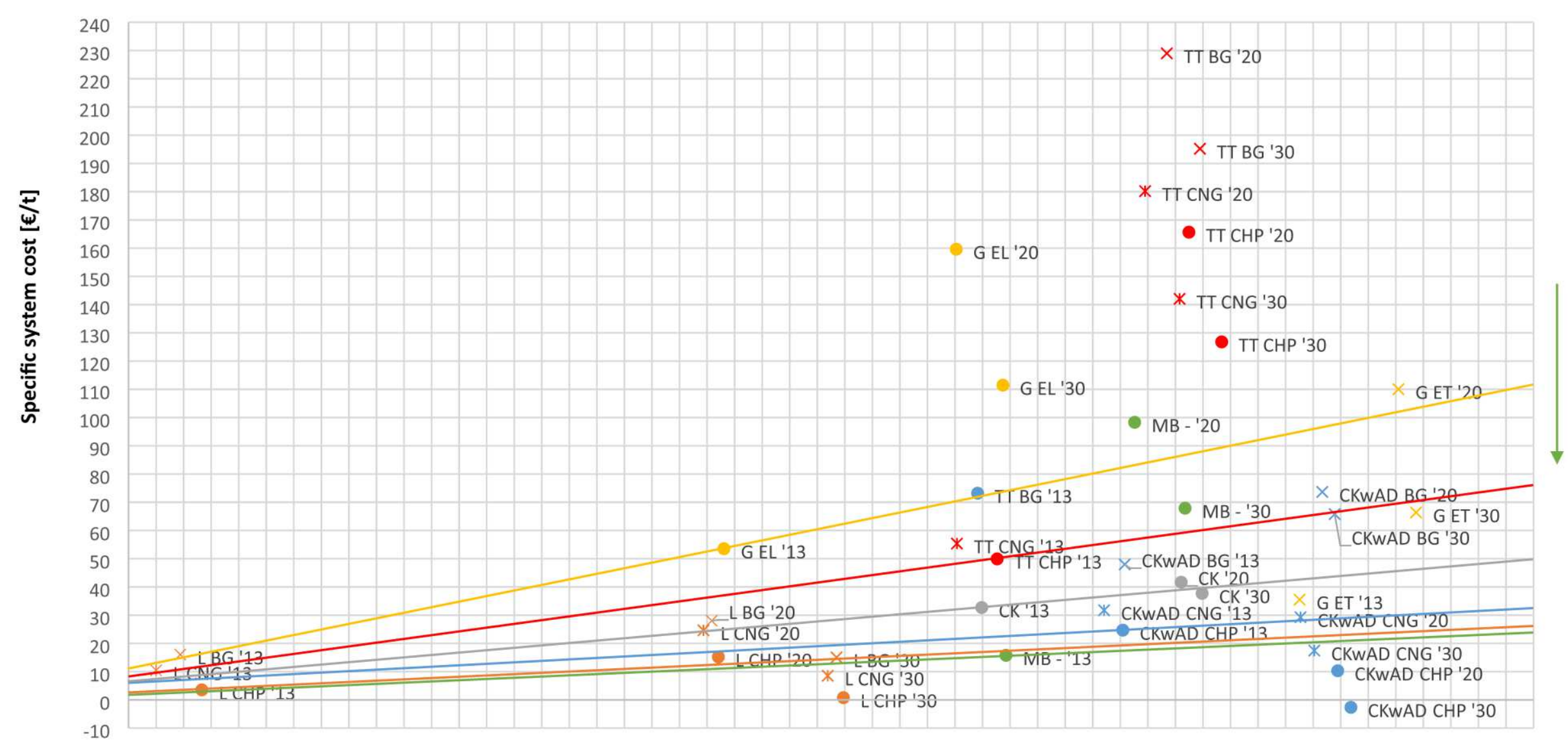

$5 \quad 6 \quad 7 \quad 8 \quad 91011121314151617181920212223242526272829303132333435363738394041424344454647484950515253545556$

Recovery of embodied energy [\%]

Figure 3. Graphical representation and comparison of Economic Efficiency of Resource Recovery (EERR) Index results 
By comparing positions of systems results (points) in different stages of satisfying EU legislation goals to EERR values (lines), overall long term sustainability of those systems can be assessed, where better results with time are achieved if the result is positioned under the corresponding line which denotes results for referent point (in 2013). Thus, it can be seen that in the case of the first analysed system, Landfill based system (L), through meeting EU goals and increasing primary waste separation, overall sustainability slightly decreases as 2020 goals are met, while it's once again increased with meeting 2030 targets, but there are no big negative oscillations while the overall trend of sustainability movement over time is positive. It is because primary separation boost material recovery and at the same time reduce energy recovery via landfill gas production. In the first period there is a greater focus on bio-waste separation, thus landfill gas production is greatly reduced with increased primary waste separation, while in the second period both material and energy recovery are increased due to increased waste generation. These results are obtained with cogeneration production from produced landfill gas, other transformations show marginally lower sustainability results while showing the same trends.

Almost the same results in the referent point are achieved with the second analysed system, Mass Burn (MB), but with achieving legislation goals for 2020 and 2030 increase in resource recovery is not on the same level with a needed increase in the WM fee, and overall sustainability greatly decreases. This is because primary separation has a positive influence on material recovery while at the same time reduces the load factor of the waste incineration plant, which needs to be compensated to achieve long-term economic sustainability of waste incinerators (Tomić et al. 2017). Between 2020 and 2030 results, an overall increase in waste quantity is bigger than the influence of an increase in primary waste separation which causes that there is more waste for incineration which increases energy production. This has a positive influence on resource recovery and the economy of the system but results are still greatly worse than in the referent point.

The third analysed scenario, Thermal treatment (TT), shows similar trending. In the referent point achieved results are significantly worse in comparison with the first two systems and they generate an even bigger cost for the increase in resource recovery when legislation goals are met. Overall sustainability results for 2030 are better than for 2020 but still greatly worse than in referent point. Behind this, there are the same reasons as in previous systems but, in this case, their influences are amplified due to increased system complexity which generates additional costs. While these additional technologies also generate additional resource consumption, their influence is counterbalanced with the additional mass flow on the gate of recovery technologies, thus, increased secondary waste separation and biogas production.

By putting more emphasis on material recovery, and by avoiding investment in a dedicated energy recovery facility, the fourth analysed scenario (Cement kiln (CK)) achieves much better results than the previous one for the referent point, while overall results do not show big oscillations when legislation targets are met. While they are slightly worse in 2020, overall sustainability results are better in 2030 when compared to the referent point, which is similar development as it was observed in the case of Landfill based system (L). This is achieved by avoiding investment in facilities with high investment costs like waste incinerators, and boosting the quantity of waste routed to material recovery. The main final disposal facility, in this case, is a cement kiln which enables payment for residual waste treatment per mass of treated waste, but at the same time, it makes the cost of the treatment subject to market fluctuations. 
Due to the overall results and derived conclusion that biogas production from bio-waste is more sustainable practice than composting, both from an environmental and economic perspective, the system analysed in the fourth scenario is additionally adapted to determine the best possible results when the same analysed technologies are used and the composting facility is exchanged with biogas plant - Cement kiln with $A D$ (CKwAD). As can be seen, results for this system show the opposite overall sustainability trends. While results for referent point are marginally worse than in the case of the first two scenarios (while still significantly better than all the rest), with an increase in primary and secondary waste separation and satisfaction of waste legislation goals, results show that overall sustainability continuously increases through 2020 and 2030, which results in positive trending of EERR results, and the best long term results in comparison with all other analysed scenarios. These results are based on positive characteristics of the Cement kiln (CK) system which are boosted with energy production from overall bio-waste, in comparison to material recovery of an only separately collected bio-waste fraction.

The last analysed scenario considers the integration of a not so widely accepted energy recovery solution - Gasification (G). It requires investment in a new energy recovery plant and, in the case of electricity generation, shows similar trending to Thermal treatment (TT) with CHP generation based system with a difference of smaller recovery of embodied energy result - it has the worse results from all analysed scenarios in the referent point and overall sustainability additionally decreases in 2020 while in till 2030 partially recover. When syngas is used for the production of ethanol, instead of CHP generation, sustainability results are significantly increased and sustainability results for referent point are only marginally worse than those for the Cement kiln with $A D$ (CKwAD) system but show the same trending as the electricitygenerating option when the other two timeframes are looked upon i.e. overall sustainability significantly decreases with meeting waste legislation goals.

Overall, it can be seen that even though at this moment some options can seem to be more sustainable, when long-range analysis results, which take into account unavoidable legislatively imposed goals, are looked upon, they can quickly become unsustainable, especially from the standpoint of the financially less powerful country/municipality. This can be clearly seen when the results of the Mass Burn (MB) and Cement kiln with AD (CKwAD) scenarios are compared. In many new EU member states, as well as candidate countries, there is a common perception that investment in a waste incinerator, even if it represents a big capital cost, is a sustainable option that could quickly solve the problem of disposing of residual waste and decrease landfilling. This perception is also confirmed by EERR results in 2013 where Mass Burn (MB) scenario shows the best results, but, mainly because of meeting other WM legislation goals, even though environmental sustainability is increased, economic decrease and overall EERR result is worse. Thus, with meeting EU legislation goals even Landfill based scenario with CHP production (L CHP) has better overall, long-term, results. On the other hand, the opposite situation is observed when the results of the Cement kiln with $A D$ (CKwAD) scenario are looked upon. The perception of scenarios based on primary and secondary separation is that they are sustainable in long run, but not in today's situation with very low primary waste separation. Results show that this perception is right on paper, but the difference in their sustainability before country/municipality started its path to meet EU legislation goals, i.e. difference in EERR results, with Mass Burn and Landfill based scenarios is minor, increase in overall sustainability with time can be expected and the best sustainability of this scenario when 2020 and 2030 WM goals are reached can be prognosed. 


\section{CONCLUSION}

European legislation set high standards regarding WM with a wider goal of making the European economy more sustainable. Requirements and goals which need to be met are increasing for years now with each newly adopted legislation framework, and some member states lag behind in meeting them and risk paying fines. Some of those member states are newer members who had shorter adaptation times and need to plan WM changes carefully to catch up with older member states. Countries that are candidates for EU membership also need to use those examples to plan their WMS in accordance with long-term EU plans if they do not want to be caught unprepared and lag behind.

In the WMS planning, the main purpose is defined through EU legislation which sets main environmental sustainability goals which need to be met through a given set of tools, like minimization of waste landfilling and maximizing its recovery, with emphasis put on material recovery. EU WM legislation also defines a pace at which those goals need to be met. In system planning, next to the main purpose of the corresponding system, its economy also needs to be taken into account. The economic side of the WMS planning is not only important from the standpoint of decision-makers and municipalities, but also from the standpoint of regular citizens as the WMS are usually financed by them. Thus, the economic sustainability of the system gains importance even more in lower-income countries where citizens cannot handle a bigger increase in the WM fee.

Because of all of that, this research analysed interconnection between environmental sustainability, calculated through primary energy return which is a proxy to the assessment of influence on raw material usage, and economic sustainability, calculated through the specific cost of a WMS which is paid by system users, i.e. WM fee. By dividing those two values Economic Efficiency of Resource Recovery (EERR) Index can be calculated and used for overall (environmental and economic) comparison and benchmarking of the WMS. Obtained results can be better analysed when they are graphically presented especially as the calculated index also represents direction coefficient for lines that denote areas of the same overall sustainability and can be used for easier comparison of possible solutions, easier presentation of the results, and easier decision-making.

Results of the time-dependent comparison of EERR analysis results show that overall perception of sustainability of WM technologies cannot be based on actual perception, which is mainly based on sustainability results of analysed system in the scope of solving of current WM problems. On the other hand, overall sustainability perception cannot either be determined based on mean sustainability results over analysed time as WMS planning covers long periods, thus, time-dependent results and sustainability trends need to be assessed to give final/informed decisions. In the scope of this, EERR index is defined which at the same time gives single score results for environmentally-economic sustainability of analysed WMS, by which analysed systems can be easily compared and rated, but also this single score result has physical meaning as it shows cost which citizens need to pay (per tonne of generated mixed MSW) for each percentage of resource recovery (expressed as a percentage of recovered embodied energy of waste), thus, it is much easier to present and understand. By calculating the EERR index for each significant time point in the WMS development, which are in this research determined by legislation defined deadlines by which specific goals need to be met, development of system sustainability is given, which represents a step further in understandable and useful WMS sustainability analysis and confirms the hypothesis of this research. 
To give an easily understandable answer to the research question, a way of graphical representation of the obtained results is developed, in which results of different scenarios can be compared in every analysed time point. As in presented research analysed time points are legislation defined, it can be seen that overall, environmentally-economic, sustainability of different WMS changes with meeting different WM legislation goals, but due to dual character of this analysis, are these changes positive or negative is dependent on which technologies used. From the results, it can be seen that sustainability perception of the analysed system usually, on average, increases with meeting stricter legislation defined WM/sustainability targets if it is heavily based on material recovery, and decreases if its dependant on dedicated energy recovery technologies.

The problem of decreasing sustainability with meeting WM goals is the most expressed in systems that are based on local energy recovery mainly due to a reduction in the quantity of waste for incineration/gasification which is directly connected to the increase in primary, but also in secondary, waste separation. To use those technologies, the problem of reduction in residual waste quantity for energy recovery needs to be compensated. This is not a problem with material recovery-based systems where an increase in primary waste separation boosts raw material recovery thus increasing overall sustainability (decreasing EERR value) or at least keeping it around the same value, despite the associated increase in system operating costs.

The only system that shows a continuous and significant decrease in the EERR index (thus, an increase in overall sustainability compared to actual sustainability perception) is a system that combines material and energy recovery, both local and outsourced. From this, it can be concluded that only a sustainable way of increasing resource recovery while keeping the cost of the system under check is through combining material and energy recovery and using already available capacities for final waste treatment before considering building new ones. This way no additional compensation for the increasing number of load hours of energy recovery facilities is needed. At the same time, if building a new energy recovery facility is needed, the production of alternative products like ethanol should be considered as it could boost overall sustainability over technologies that are widely used in WM. Through the presented results and discussion, a comprehensive answer to the research question is given.

As it can be seen, EERR results in a presented form represent a useful tool for decision-making in WM, especially as the quality decision-making process needs to take into account the impact of expected changes on the overall sustainability of the systems under consideration and evaluate how they will affect the current perception of used technologies. In this context, the EERR index can be a useful tool that can help not only in the decision-making process but also in presenting the obtained results to wider groups of people as they are more understandable due to well defined physical meeting of the EERR index, as well as a clear graphical representation of changes in perceived sustainability.

Overall, together with its graphical representation, EERR analysis shows the resistance of systems sustainability to changes that can be expected in the future, and how systems can cope with changes like increased primary separation or increase in the waste collection which can lead to a decrease in the quantity of waste for energy recovery, increase in the quantity of waste for composting, increase of waste quantity for recycling, etc. This new view on the sustainability of WM can help decision-makers, especially in new member states, to make quality and sustainable (environmentally and economically) decisions faster which is in line EU Circular Economy Action Plan and its main idea to gradually equalize the level of best practice across the EU Member States. 
Next to its use in WMS analysis, this approach could find its application in sustainability analysis of other systems and technologies whose implementation is conditioned not only by environmental but also, at the same time, by economic sustainability. Also, as a part of the future work, it is planned to expand this analysis to encompass social acceptance from the standpoint of how citizens perceive/accept individual technologies as a part of the WMS.

\section{ACKNOWLEDGMENTS}

This work has been fully supported by the Croatian Science Foundation under the project NEOPLAST (IP-01-2018-3200) - Smart energy carriers in recovery of plastic waste.

\section{DECLARATIONS}

\section{Funding}

This work has been fully supported by the Croatian Science Foundation under the project NEOPLAST (IP-01-2018-3200) - Smart energy carriers in recovery of plastic waste.

\section{Conflicts of interest/Competing interests}

The authors declare that they have no known competing financial interests or personal relationships that could have appeared to influence the work reported in this paper.

\section{Availability of data and material}

All used data and materials are referenced in the manuscript.

\section{Code availability}

Not applicable

\section{REFERENCES}

Aleluia J, Ferrão P (2017) Assessing the costs of municipal solid waste treatment technologies in developing Asian countries. Waste Manag 69:592-608. https://doi.org/10.1016/j.wasman.2017.08.047

Ardolino F, Lodato C, Astrup TF, Arena U (2018) Energy recovery from plastic and biomass waste by means of fluidized bed gasification: A life cycle inventory model. Energy 165:299314. https://doi.org/10.1016/j.energy.2018.09.158

Athena Sustainable Materials Institut (2004) U.S. LCI Database Project Development Guidelines. https://www.nrel.gov/docs/fy04osti/34275.pdf. Accessed 11 Dec 2019

AZO (2014) Izvješće o komunalnom otpadu za 2013 [Municipal Waste Report for 2013]. http://www.haop.hr/sites/default/files/uploads/dokumenti/021 otpad/Izvjesca/komunalni/OTP Izvje\%C5\%A1\%C4\%87e\%20o\%20komunalnom\%20otpadu_2013..pdf. Accessed 02 Dec 2019 
Bel G, Fageda X (2010) Empirical analysis of solid management waste costs: Some evidence from Galicia, Spain. Resour Conserv Recycl 54:187-193. https://doi.org/10.1016/j.resconrec.2009.07.015

Boffardi R, De Simone L, De Pascale A, et al (2021) Best-compromise solutions for waste management: Decision support system for policymaking. Waste Manag 121:441-451. https://doi.org/10.1016/j.wasman.2020.12.012

Bueno G, Latasa I, Lozano PJ (2015) Comparative LCA of two approaches with different emphasis on energy or material recovery for a municipal solid waste management system in Gipuzkoa. Renew Sustain Energy Rev 51:449-59. https://doi.org/10.1016/j.rser.2015.06.021

Chanthakett A, Arif MT, Khan MMK, Oo AMT (2021) Performance assessment of gasification reactors for sustainable management of municipal solid waste. J Environ Manage 291:112661. https://doi.org/10.1016/j.jenvman.2021.112661

Chifari R, Lo Piano S, Matsumoto S, Tasaki T (2017) Does recyclable separation reduce the cost of municipal waste management in Japan? Waste Manag 60:32-41. https://doi.org/10.1016/j.wasman.2017.01.015

Colvero DA, Ramalho J, Gomes APD, et al (2020) Economic analysis of a shared municipal solid waste management facility in a metropolitan region. Waste Manag 102:823-837. https://doi.org/10.1016/j.wasman.2019.11.033

Commission of the European Communities (2003) Integrated Product Policy - Building on Environmental Life-Cycle Thinking - $\operatorname{COM}(2003) 302$ final. http://ec.europa.eu/transparency/regdoc/rep/1/2003/EN/1-2003-302-EN-F1-1.Pdf. Accessed 20 Jan 2020

da Costa LG, Ferreira JCE, Kumar V, Garza-Reyes JA (2020) Benchmarking of sustainability to assess practices and performances of the management of the end of life cycle of electronic products: a study of Brazilian manufacturing companies. Clean Technol Environ Policy. https://doi.org/10.1007/s10098-020-01947-3

de Brito RC, Barros RM, dos Santos IFS, et al (2021) Municipal solid waste management and economic feasibility for electricity generation from landfill gas and anaerobic reactors in a Brazilian state. Environ Technol Innov 22:101453. https://doi.org/10.1016/j.eti.2021.101453

den Boer E, den Boer J, Jager J (2005) Waste Management Planning and Optimisation (LCA IWM). Obidem-Verlag. Stuttgart.

den Boer J, den Boer E, Jager J (2007) LCA-IWM: A decision support tool for sustainability assessment of waste management systems. Waste Manag 27:1032-1045. https://doi.org/10.1016/j.wasman.2007.02.022

Ducharme C (2010) Technical and Economic Analysis of Plasma-Assisted Waste-To- Energy Processes. Columbia University pp. 1-75. http://gwcouncil.org/wpcontent/uploads/2020/10/ducharme_thesis.pdf. Accessed 01 Oct 2020

Ecoinvent Centre (2016) Ecoinvent Database v3.2. Inf. Syst. Sustain. Dev. https://doi.org/10.4018/978-1-59140-342-5.ch003

EcoMondis (2018) Waste Derived Alternative Fuels. http://ecomondis.com/brochure.pdf. Accessed 11 Jun 2019

Energinet.dk (2012) Technology data for energy plants. https://energiatalgud.ee/img_auth.php/4/42/Energinet.dk._Technology_Data_for_Energy_Pla nts._2012.pdf. Accessed 30 Jun 2019 
$\begin{array}{lllll}\text { European } & \text { Commission } & \text { (2020) Environment } & \text { Waste. }\end{array}$ http://ec.europa.eu/environment/waste/index.htm. Accessed 1 Oct 2020

European Commission (2011) Roadmap to a Resource Efficient Europe - COM/2011/571. https://eur-lex.europa.eu/legal-content/EN/TXT/?uri=CELEX:52011DC0571. 1 Oct 2020

European Commission (2015) Closing the loop: Commission adopts ambitious new Circular Economy Package to boost competitiveness, create jobs and generate sustainable growth. http://europa.eu/rapid/press-release_IP-15-6203_en.htm. Accessed 1 Oct 2020

European Council (1999) Directive 1999/31/EC of 26 April 1999 on the landfill of waste. https://eur-lex.europa.eu/legal-content/EN/TXT/?uri=celex\%3A31999L0031. 1 Oct 2020

European Parliament (2018). Briefing EU Legislation in Progress from July 2018 - Circular economy package Four legislative proposals on waste. http://www.europarl.europa.eu/RegData/etudes/BRIE/2018/625108/EPRS_BRI(2018)625108 _EN.pdf. Accessed 1 Oct 2020

European Parliament (2020). Resolution of 15 January 2020 on the European Green Deal (2019/2956(RSP)). $\quad$ https://www.europarl.europa.eu/doceo/document/TA-9-20200005_EN.html. Accessed 1 Oct 2020

European Parliament and Council (2008) Directive 2008/98/EC of 19 November 2008. on waste. https://eur-lex.europa.eu/legal-content/EN/TXT/?uri=celex\%3A32008L0098. Accessed 1 Oct 2020

European Parliament and Council (2015). Communication from the Commission to the European Parliament, the Council, the European Economic and Social Committee and the Committee of the Regions Closing the loop - An EU Action Plan for the Circular Economy COM/2015/0614 final. https://eur-lex.europa.eu/legalcontent/EN/TXT/?uri=CELEX:52015DC0614. Accessed 1 Oct 2020

European Parliament and Council (2018a) Directive (EU) 2018/851 of The European Parliament and of The Council of 30 May 2018 amending Directive 2008/98/EC on waste. https://eur-lex.europa.eu/legal-content/EN/ALL/?uri=CELEX\%3A32018L0851. Accessed 1 Oct 2020

European Parliament and Council (2018b). Directive (EU) 2018/850 of the European Parliament and of the Council of 30 May 2018 amending Directive 1999/31/EC on the landfill of waste. https://eur-lex.europa.eu/legalcontent/EN/TXT/?uri=uriserv:OJ.L_.2018.150.01.0100.01.ENG. Accessed 1 Oct 2020

European Parliament and Council (2018c). Directive (EU) 2018/852 of the European Parliament and of the Council of 30 May 2018 amending Directive 94/62/EC on packaging and packaging waste. https://eur-lex.europa.eu/legalcontent/EN/TXT/?uri=uriserv:OJ.L_.2018.150.01.0141.01.ENG\&toc=OJ:L:2018:150:TOC. Accessed 1 Oct 2020

European Parliament and Council (2018d). Directive (EU) 2018/849 of the European Parliament and of the Council of 30 May 2018 amending Directives 2000/53/EC on end-of-life vehicles, 2006/66/EC on batteries and accumulators and waste batteries and accumulators, and 2012/19/EU on waste electrical and electronic equipment. https://eur-lex.europa.eu/legalcontent/EN/TXT/PDF/?uri=CELEX:32018L0849\&rid=4. Accessed 1 Oct 2020

Eurostat (2020a) Generation of waste by waste category, hazardousness and NACE Rev. 2 activity. (online data codes: env_wasgen). http://ec.europa.eu/eurostat. Accessed 1 Oct 2020 
Eurostat (2020b) Waste statiscitcs. https://ec.europa.eu/eurostat/statisticsexplained/index.php/Waste_statistics. Accessed 1 Oct 2020

Eurostat (2020c) Treatment of waste by waste category, hazardousness and waste management operations. (online data codes: env_wastrt). http://ec.europa.eu/eurostat. Accessed 1 Oct 2020

Franchetti M (2013) Economic and environmental analysis of four different configurations of anaerobic digestion for food waste to energy conversion using LCA for: A food service provider case study. J Environ Manage 123:42-48. https://doi.org/10.1016/j.jenvman.2013.03.003

Gilbert JC (2009) Comparison and analysis of energy consumption in typical Iowa swine finishing systems. Iowa State University, Digital Repository. https://doi.org/10.31274/etd180810-2311

Giuliano A, Catizzone E, Freda C, Cornacchia G (2020) Valorization of OFMSW DigestateDerived Syngas toward Methanol, Hydrogen, or Electricity: Process Simulation and Carbon Footprint Calculation. Processes 8:526. https://doi.org/10.3390/pr8050526

Giugliano M, Cernuschi S, Grosso M, Rigamonti L (2011) Material and energy recovery in integrated waste management systems. An evaluation based on life cycle assessment. Waste Manag 31:2092-2101. https://doi.org/10.1016/j.wasman.2011.02.029

Government of India (2018) Ministry of Housing and Urban Affairs - Guidelines on Usage of Refuse Derived Fuel in Various Industries. http://164.100.228.143:8080/sbm/content/writereaddata/Guidelines\%20on\%20RDF\%20Usag e.pdf. Accessed 18 Jun 2019

Government of the Republic of Croatia (2013) Tarifni sustav za proizvodnju električne energije iz obnovljivih izvora energije i kogeneracije [Tariff system for electricity from renewable energy sources and cogeneration]. https://narodnenovine.nn.hr/clanci/sluzbeni/2013_11_133_2888.html. Accessed 18 Jun 2019

Haig S, Morrish L, Morton ., Onwuamaegbu U, Speller P, Wilkinson S (2018) Plastics to oil products IFM002 final report, Zero Waste Scotland. https://www.zerowastescotland.org.uk/sites/default/files/Plastics\%20to\%20Oil\%20Report.pdf . Accessed 10 Jul 2019

HEP (2019) Cjenik [Pricelist]. http://www.hep.hr/toplinarstvo/en/customers/price.aspx. Accessed 15 Jul 2019

Huijbregts MAJ, Rombouts LJA, Hellweg S, et al (2006) Is cumulative fossil energy demand a useful indicator for the environmental performance of products? Environ Sci Technol 40:641648. https://doi.org/10.1021/es051689g

Iacovidou E, Voulvoulis N (2018) A multi-criteria sustainability assessment framework: development and application in comparing two food waste management options using a UK region as a case study. Environ Sci Pollut Res 25:35821-35834. https://doi.org/10.1007/s11356-018-2479-zInternational Standardisation Organisation (2006a) ISO 14040:2006. In: Environmental management - life cycle assessment - principles and framework. CEN, Brussels

International Standardisation Organisation (2006b) ISO 14044:2006. In: Environmental management - life cycle assessment - requirements and guidelines. CEN, Brussels

ISWA (2015) Circular Economy: Carbon, Nutrients and Soil. Vienna, Austria. https://www.iswa.org/fileadmin/galleries/Task_Forces/Task_Force_Report_4.pdf. Accessed 20 Feb 2019 
Jadhao SB, Shingade SG, Pandit AB, Bakshi BR (2017) Bury, burn, or gasify: assessing municipal solid waste management options in Indian megacities by exergy analysis. Clean Technol Environ Policy 19:1403-1412. https://doi.org/10.1007/s10098-017-1338-9

Karellas S, Boukis I, Kontopoulos G (2010) Development of an investment decision tool for biogas production from agricultural waste. Renew Sustain Energy Rev 14:1273-1282. https://doi.org/10.1016/j.rser.2009.12.002

Kaufman SM, Krishnan N, Themelis NJ (2010) A Screening Life Cycle Metric to Benchmark the Environmental Sustainability of Waste Management Systems. Environ Sci Technol 44:5949-5955. https://doi.org/10.1021/es100505u

Koido K, Takeuchi H, Hasegawa T (2018) Life cycle environmental and economic analysis of regional-scale food-waste biogas production with digestate nutrient management for fig fertilisation. J Clean Prod 190:552-562. https://doi.org/10.1016/j.jclepro.2018.04.165

Kremer I, Tomić T, Katančić Z, et al (2020) Catalytic decomposition and kinetic study of mixed plastic waste. Clean Technol Environ Policy. https://doi.org/10.1007/s10098-020-01930-y

Letsrecycle (2018) Secondary material market prices indicators. https://www.letsrecycle.com/. Accessed 30 Nov 2019

Luz FC, Rocha MH, Lora EES, et al (2015) Techno-economic analysis of municipal solid waste gasification for electricity generation in Brazil. Energy Convers Manag 103:321-337. https://doi.org/10.1016/j.enconman.2015.06.074

Luttenberger LR (2020) Waste management challenges in transition to circular economy - Case of Croatia. J Clean Prod 256:120495. https://doi.org/10.1016/j.jclepro.2020.120495

McDougall FR, Franke M, Hindle P, White PR (2001) Integrated Solid Waste Management: a Life Cycle Inventory. Blackwell https://onlinelibrary.wiley.com/doi/pdf/10.1002/9780470999677.fmatter. Accessed 20 Feb 2019

Medina-Mijangos R, Seguí-Amórtegui L (2021) Technical-economic analysis of a municipal solid waste energy recovery facility in Spain: A case study. Waste Manag 119:254-266. https://doi.org/10.1016/j.wasman.2020.09.035

Milutinović B, Stefanović G, Dassisti M, et al (2014) Multi-criteria analysis as a tool for sustainability assessment of a waste management model. Energy 74:190-201. https://doi.org/10.1016/j.energy.2014.05.056Minoglou M, Komilis D (2013) Optimizing the treatment and disposal of municipal solid wastes using mathematical programming-A case study in a Greek region. Resour Conserv Recycl 80:46-57. https://doi.org/10.1016/j.resconrec.2013.08.004

Mitchell G (2015) Building a Business Case for Compressed Natural Gas in Fleet Applications. National Renewable Energy Laboratory. https://afdc.energy.gov/files/u/publication/business_case_cng_fleets.pdf. Accessed 21 Jun 2019

Mužinić M, Pašalić G, Martina C, Fundurulja D, Domanovac T (2014) Plan gospodarenja otpadom Grada Zagreba [Waste management plan of the City of Zagreb. City of Zagreb. https://eko.zagreb.hr/UserDocsImages/arhiva/dokumenti/okoli\%C5\%A1/strate\%C5\%A1ka\% 20studija/PGO.pdf. Accessed 05 Jan 2019

Norris GA (2001) Integrating Economic Analysis into LCA. Environ Qual Manag 10:59-64. https://doi.org/10.1002/tqem.1006 
NREL (2016) USLCI database. Available from: http://www.nrel.gov/lci/. Accessed 21 Jan 2019

Paes MX, de Medeiros GA, Mancini SD, et al (2020) Municipal solid waste management: Integrated analysis of environmental and economic indicators based on life cycle assessment. J Clean Prod 254:119848. https://doi.org/10.1016/j.jclepro.2019.119848Penny T, Collins M, Aumônier S, et al (2013) Embodied Energy as an Indicator for Environmental Impacts - A Case Study for Fire Sprinkler Systems. In: Håkansson A, Höjer M, Howlett RJ, Jain LC (eds) Sustainability in Energy and Buildings. Smart Innovation, Systems and Technologies. Springer, Berlin, Heidelberg, pp 555-565. https://doi.org/10.1007/978-3-642-36645-1_52

Puig R, Fullana-i-Palmer P, Baquero G, Riba J-R, Bala A (2013) A Cumulative Energy Demand indicator (CED), life cycle based, for industrial waste management decision making. Waste Manag 33:2789-97. https://doi.org/10.1016/j.wasman.2013.08.004

Ramos A, Berzosa J, Espí J, et al (2020) Life cycle costing for plasma gasification of municipal solid waste: A socio-economic approach. Energy Convers Manag 209:112508. https://doi.org/10.1016/j.enconman.2020.112508

Rohrlich M, Mistry M, Martens PN, et al (2000) A method to calculate the Cumulative Energy Demand (CED) of lignite extraction. Int $J$ Life Cycle Assess 5:369-373. https://doi.org/10.1007/bf02978675

RPS (2014) Dublin Waste to Energy - Waste Market Assessment. https://www.indymedia.ie/attachments/oct2014/rpsreportfinal.pdf. Accessed 16 Jun 2019

Saad W, Taleb A (2018) The causal relationship between renewable energy consumption and economic growth: evidence from Europe. Clean Technol Environ Policy 20:127-136. https://doi.org/10.1007/s10098-017-1463-5

Schneider DR, Tomić T, Raal R (2021) Economic viability of the deposit refund system for beverage packaging waste - identification of economic drivers and system modelling. J Sustain Dev Energy, Water Environ Syst N/A:0-0. https://doi.org/10.13044/j.sdewes.d9.0386

Schäfer A, Moser A (2012) Dispatch optimization and economic evaluation of distributed generation in a virtual power plant. 2012 IEEE Energytech, Energytech 2012. https://doi.org/10.1109/EnergyTech.2012.6304655

Tomić T, Ćosić B, Schneider DR (2016) Influence of legislative conditioned changes in waste management on economic viability of MSW-fuelled district heating system: Case study. Therm Sci 20:1105-1120. https://doi.org/10.2298/TSCI160212114T

Tomić T, Dominković DF, Pfeifer A, et al (2017) Waste to energy plant operation under the influence of market and legislation conditioned changes. Energy 137:1119-1129. https://doi.org/10.1016/j.energy.2017.04.080

Tomić T, Schneider DR (2017) Municipal solid waste system analysis through energy consumption and return approach. J Environ Manage 203:973-987. https://doi.org/10.1016/j.jenvman.2017.06.070

Tomić T, Schneider DR (2018) The role of energy from waste in circular economy and closing the loop concept - Energy analysis approach. Renew Sustain Energy Rev 98:268-287. https://doi.org/10.1016/j.rser.2018.09.029

Tomić T, Schneider DR (2020) Circular economy in waste management - Socio-economic effect of changes in waste management system structure. J Environ Manage 267:. https://doi.org/10.1016/j.jenvman.2020.110564 
US Department of Energy (2010) Production of Mixed Alcohols from Municipal Solid Waste via Gasification. https://www.energy.gov/sites/prod/files/2014/03/f14/msw_design_case.pdf. Accessed 04 Jun 2019

USEPA (2019) AP-42 chapter 2.4 Municipal solid waste landfills. https://www3.epa.gov/ttnchie1/ap42/ch02/final/c02s04.pdf. Accessed 02 Aug 2019

Vlachokostas C, Michailidou AV, Achillas C (2021) Multi-Criteria Decision Analysis towards promoting Waste-to-Energy Management Strategies: A critical review. Renew Sustain Energy Rev 138:110563. https://doi.org/10.1016/j.rser.2020.110563

Vučijak B, Kurtagić SM, Silajdžić I (2016) Multicriteria decision making in selecting best solid waste management scenario: a municipal case study from Bosnia and Herzegovina. J Clean Prod 130:166-174. https://doi.org/10.1016/j.jclepro.2015.11.030

Warren WKEH (2012) A techno-economic comparison of biogas upgrading technologies in Europe. Jyväskylä. University of Jyväskylä. citeseerx.ist.psu.edu/viewdoc/download?doi=10.1.1.456.1353\&rep=rep1\&type=pdf. Accessed 23 Jun 2019

Weidema BP, Bauer C, Hischier R, Mutel C, Nemecek T, Reinhard J, Vadenbo CO, Wernet G (2013) Overview and Methodology - Data Quality Guideline for the Ecoinvent Database Version 3, Ecoinvent Report 1(v3). Accessed 2 Jan 2019

Yadav VG, Yadav GD, Patankar SC (2020) The production of fuels and chemicals in the new world: critical analysis of the choice between crude oil and biomass vis-à-vis sustainability and the environment. Clean Technol Environ Policy 22:1757-1774. https://doi.org/10.1007/s10098-020-01945-5

Zhang R, Ma X, Shen X, et al (2020) PET bottles recycling in China: An LCA coupled with LCC case study of blanket production made of waste PET bottles. J Environ Manage 260:. https://doi.org/10.1016/j.jenvman.2019.110062 